\title{
A METHOD FOR DERIVING DATA FROM THE SOVIET CENSUSES 1959, 1970, 1979, 1989 The case of the Ukraine
}

\author{
Masayuki KUWATA \\ (Tokyo Institute of Technology) \\ [Key words: Soviet Census, mother tongue choice, \\ multiple regression analysis]
}

\section{Introduction}

The subject of this paper is the development of a method for determining the factors that influence the mother tongue choice of Ukrainian citizens during the period from 1959 to 1989 , by using the data from the Soviet census. To be precise, the purpose of this paper is to propose a model which captures the dynamics of language selection by Ukrainian citizens using statistical data and analytical methods. Statistical methods based on the census materials are the focus for the following reasons:

1) Much attention has been paid to political analysis concerning language policy in the former USSR but political and legislative procedures within the political arena are quite removed from actual language selection by its citizens. In other words, the evaluation for language policies in the former USSR requires the grasp of its peoples' language choice dynamics. The Soviet census provides convenient records for assessing these transitions.

2) Some earlier literatures provide statistical analyses of census materials but most revolve around the actual raw data of language choice itself. The latest studies show that language choice data overestimated the maintenance rates of national languages by indigenous peoples. Thus, the results of current studies should be considered in light of statistical analysis based on the data from Soviet censuses. 
3) Once an appropriate model is developed, comparison studies will be easier. Modeling the social structure relating to mother tongue selection among Ukrainian people would not only help understand the public trend in language choice but also provide further possibilities for comparative analysis among the former USSR.

\section{Past literature and this paper's strategy}

This section addresses former analyses and their problems. There are two fields of statistical analyses that describe the former Soviet Union's language problems. One is the research on the Soviet Union as a whole and the other is the research on each republic which constitutes the former Soviet Union. The principal work on the former is that by Brian Silver and work on the latter (about the Ukraine) is by Dominique Arel. Arel focused on the Ukrainian census results in his doctoral thesis ${ }^{1}$. This thesis has the advantage that 4 time census results $(1959,1970$, 1979, 1989) illustrating the Ukrainian situation are dealt with, but the method of analysis is mere comparison of percentage data regarding language selection. As he himself referred to the problem of validity on the census results dealing with language selections in the Ukraine ${ }^{2}$, it is misleading to use it as a definitive indicator on real language choice by Ukrainian peoples and his approach is not statistically rational. Silver's research focuses on estimating the national language maintenance rate by indigenous people or so-called russification. The contentious point for such estimation is that if the raw data have errors, the result of estimation itself will be invalid. The cause of this error lies in the fact that the census questionnaire includes an ambiguous expression that asks for the "mother tongue" (rodnoi iazik). As indicated in Arel's paper, the census could contain errors regarding language choice, because "mother tongue" could be interpreted as 'the conversational language in daily life,' or 'the language of acquired in childhood,' or 'the most fluent language' etc. ${ }^{3}$ As Shiokawa quoted from Gubolgo, "Mother tongue" was often interpreted as the one's own national language by most people in the former USSR and even when a person was not fluent in his or her national language, there were some cases in which he or she claimed his or her national language as his or her "mother tongue"4. Therefore, although Silver's estimations are elaborate enough, as indicated in the aforementioned second goal of this paper, those concerning language selection from the 1970 


\section{A METHOD FOR DERIVING DATA}

Soviet census are to some extent misleading 5 . But Silver's other works show us the availability of the census data. He dealt with Soviet censuses for some time and his analyses concerning the $1959^{6}$ and 1970 censuses $^{7}$ offer some clues. In both papers, Silver ran regression analyses in which language choice criteria are dependent variables and some other criteria such as urbanization rate, interethnic communication and religious belongings are independent variables. Applying this method, his analyses are freed from errors caused by ambiguous expressions in the census questionnaire to grasp the social structure that explains citizen's language choice. That is to say, his works are still persuasive except for estimates of language choice rates. Nevertheless there are weaknesses in his development. The first problem is that he did not calculate the standardized estimate for the independent variables. Namely, his results are more appropriate for estimating language choice rate than for describing the social structure model for language selection. The second problem is the inconvenience in analyzing Ukrainian circumstances. Specifically, his formulations developed through multiple regression analysis have inappropriate independent variables. For example, if you intend to take both the Russian population rate and urbanization criterion as independent variables, it is impossible to analyze the Ukrainian case because there is a strong correlation between the urbanization rate and Russian population in Ukraine from 1959 to 1989. Thus, those formulations that have urbanization rate and Russian population rate as independent variables should have multi-colinearity. The Pearson correlation coefficient between those 2 variables is 0.79 and significant to below 0.01 . Despite these obstacles, the multiple regression analysis itself has the potential of constituting a model of the social dynamics so long as independent variables were appropriate. So, in order to obtain such variables, this paper takes the following steps:

1) Collect indices taken at the provincial level in the Ukraine

2) Run the factor analysis by varimax rotation with the indices mentioned above except for language choice criteria, and derive the latent variables

3) Run a multiple regression analysis in which language selection criteria are dependent variables and latent variables' factor scores distilled above are independent variables

4) Trace the dynamics of the influential model of language selection

In particular, the second provision enables us to avoid the inter-correlations among dependent variables and to compare 4 census models. In short, this paper's 
concept is as follows. Census data have some errors caused of vague expressions in census questionnaire regarding mother tongue, but the transition of language selections themselves should reflect the genuine cohort of particular language orientation of its speakers because the questionnaire asking respondents' mother tongue kept the same format. Thus, language choice models consisting of the same latent variables should clearly display the influential dynamism of each latent variable.

\section{Data and processing methods}

\section{Data}

This section explains the data and the steps of analysis. Soviet censuses were registered in 1920, 1926, 1937, 1939, 1959, 1970, 1979 and 1989 ${ }^{8}$. But L'viv was not under Soviet Ukraine until 1939 and Crimea until 1954. In other words, the Ukraine has occupied the same territory since 1954. Consequently, this paper deals with 4 Soviet censuses from 1959 to 1989 collected about every 10 years. Data are derived as follows from each census. (All data is at the provincial level.)

1. Macro criteria (2 variables) $)^{9}, 10,11,12$ : provincial population rate to whole Ukraine population* (SIZE), urban population rate in each province (URB), 2. Ethnicity dispersion (3 variables) ${ }^{13}$ : Ukrainian population (UKR), Russian population (RUS), other than Ukrainian and Russian population (OTH)

3. Selection of mother tongue ( 8 variables $)^{14}$ : people who claim Ukrainian as their mother tongue (L_UK), people who claim Russian as their mother tongue (L_RUS), Ukrainians who claim Ukrainian as their mother tongue (UK_UK), Ukrainians who claim Russian as their mother tongue (UK_R), Russians who claim Russian as their mother tongue (R_R), Russians who claim Ukrainian as their mother tongue (R_UK), other than Ukrainian and Russian who claim Ukrainian as their mother tongue (O_UK), other than Ukrainians and Russians who claims Russian as their mother tongue (O_R) 4. Educational level criteria (7 variables) ${ }^{15,16,17,18}$ : High education (UNIV), special high school (SP_H), high school $(\mathrm{H})$, no high school (B_H), secondary education* (SCND), elementary school* (EL), no elementary school education (B_EL)

Some other criteria were derived from another source. 
5. Economic and other criteria (7 variables): average monthly salary of kolkhoz labors (KOL) ${ }^{19}$, average monthly salary of sovkhoz labors (SOV) ${ }^{20}$, commercial transaction including the food service industry (GDS $)^{21}$, GDS/ provincial population* (TOB), percentage of specialists with higher education among all labors (PROF) ${ }^{22}$, birth rate (BIRTH), death rate (DEATH $)^{23}$

Consequently a data set which consists of 27 variables and 100 observations (Ukrainian 25 provinces $\times 4$-time) is derived.

Note

1) *Author compiled.

2) Symbols in parentheses are names of each variable for statistical analysis. These signs are used in tables and figures later.

3) Economic and other criteria data were taken in 1960, 1970, 1980 and 1987 but it is thought acceptable to relate them to the censuses of 1959 , 1970, 1979 and 1989 respectively.

II. Extracting the latent variables

All data except for mother tongue selection were submitted to factor analysis first. This process distills 5 factors from 19 variables. Because factor 5 consists of all but Ukrainian and Russian populations (OTH), this variable is omitted and the factor analysis was done once again. Then, four factors were extracted

Table 1. Rotated factor pattern

\begin{tabular}{l|c|c|c}
\hline Variables & FACTOR1 & FACTOR2 & FACTOR3 \\
\hline SOV & 0.950 & 0.189 & 0.156 \\
H & 0.944 & 0.207 & 0.084 \\
SCND & 0.936 & 0.250 & 0.149 \\
KOL & 0.932 & 0.205 & 0.220 \\
SP_H & 0.892 & 0.283 & 0.241 \\
DEATH & 0.866 & 0.065 & -0.287 \\
TOB & 0.779 & -0.211 & 0.025 \\
UNIV & 0.706 & 0.406 & 0.347 \\
BIRTH & -0.677 & -0.328 & 0.122 \\
\hline SIZE & -0.105 & 0.931 & 0.237 \\
PROF & 0.444 & 0.815 & 0.279 \\
GDS & 0.476 & 0.770 & 0.339 \\
URB & 0.343 & 0.642 & 0.578 \\
\hline RUS & 0.050 & 0.309 & 0.907 \\
UKR & -0.010 & -0.232 & -0.941 \\
\hline
\end{tabular}

Rotation method: Varimax 
from those 18 variables. This result shows that Factor 1 and Factor 3 reflect high and low educational level respectively. Thus Factor 3's elements (B_H, EL, ) and another criterion (B_EL) that mean relative low educational level were eliminated and the third factor analysis was run with 15 variables. Three factors were taken from those 15 variables and the rotated factor pattern is shown in Table 1.

Factor 3's elements are Russian population and Ukrainian population in each province. Therefore this factor is undisputedly named the ethnic factor. Factor 1 consists of farmer's income (SOV, KOL), relatively high educational level $(\mathrm{H}$, SCND, SP_H) and money circulation per person (TOB). It would appear that

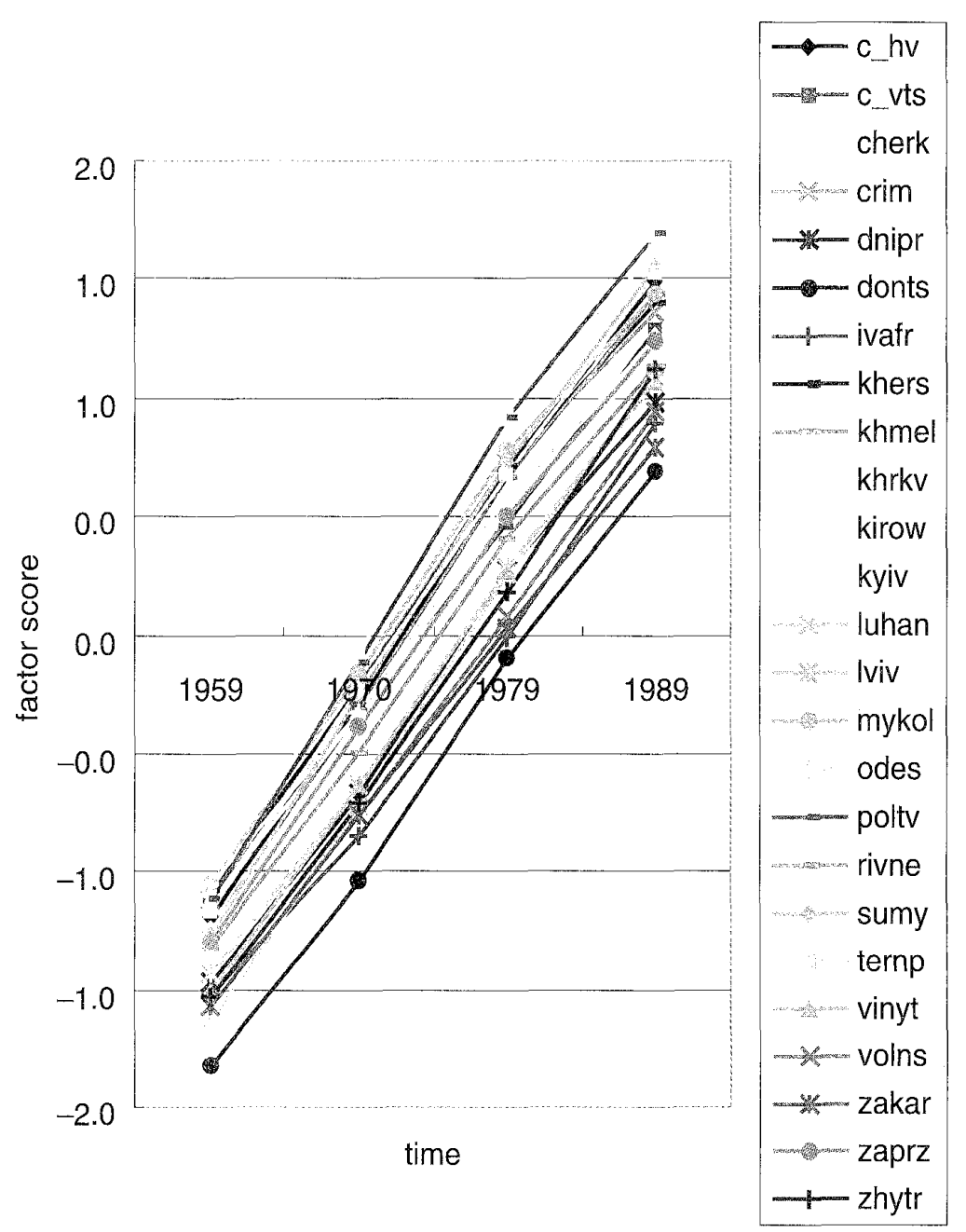

Figure 1. Factor 1 


\section{A METHOD FOR DERIVING DATA}

this factor reflects social development. In order to confirm, a line graph of the factor scores for Factor 1 is drawn as Figure 1. All provinces' factor scores climb up as time goes by without any exceptions. This confirms its designation as the social development factor. The interpretation of factor 2 is somehow difficult. As Table 1 shows, Factor 2 is composed of variables as follows; provincial population (SIZE), specialist rate among all labors (PROF), commercial transaction (GDS) and urban population rate (URB). Because there are variables for provincial size and urban population rate, it could be thought as the urbanization factor. But if this supposition is true, factor loading for URB (0.642; The lowest of the three variables) is contradictory. It is remarkable that provincial population and specialist rate indicate high factor loadings $(0.931$

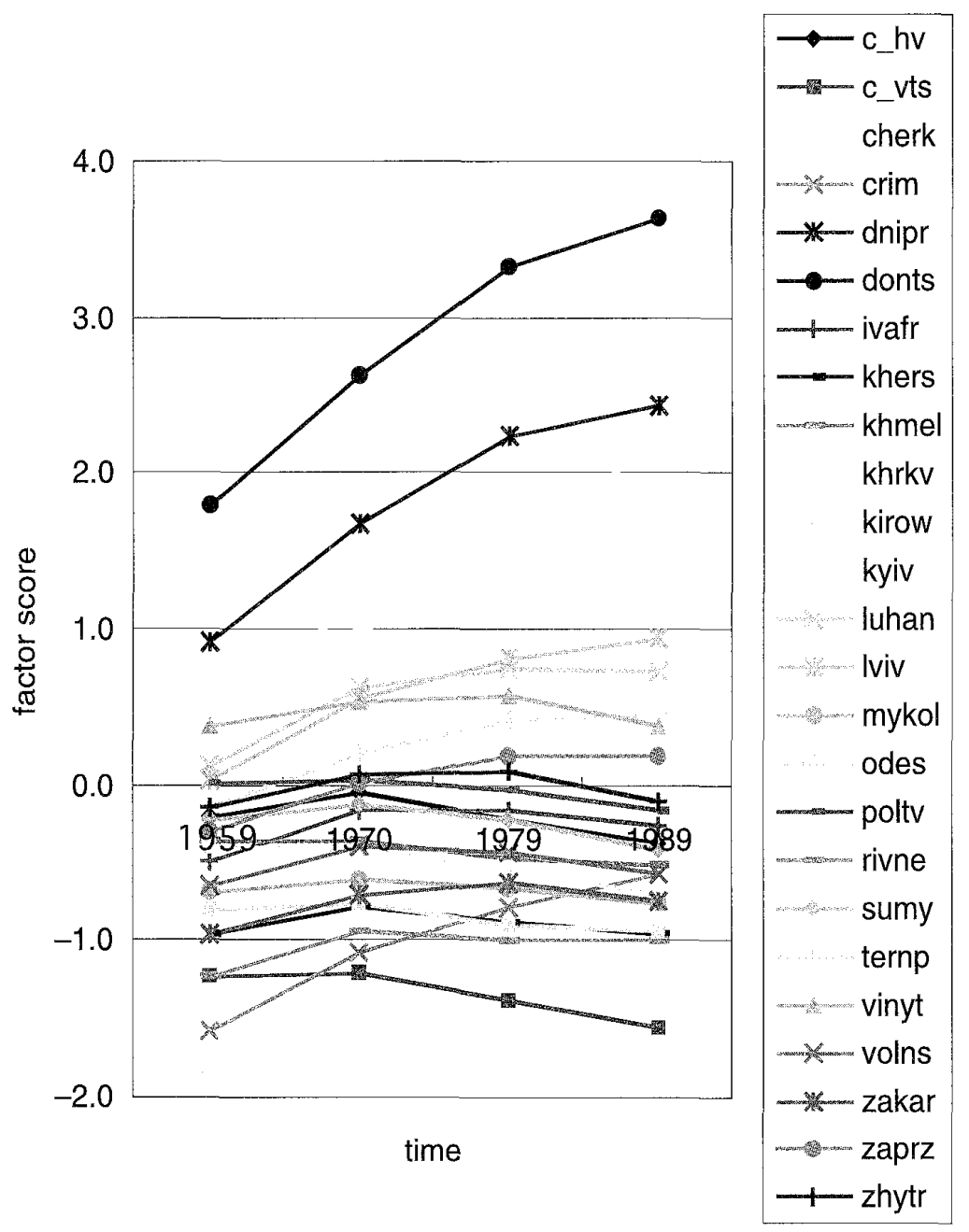

Figure 2. Factor 2 
and 0.815 respectively). Taking into the consideration these facts, we check the referring graph of factor scores drawn up as Figure 2. In 1989, factor scores show the following order; Donetsk, Dnipropetrovsk, Kyiv, Kharikiv. This order reminds one of Ukraine's industrialized provinces. The reason why the data set for factor analysis does not contain the data for industrial coefficients is just the lack of such data which are available for the inter-provincial comparison in the same time scale. The only industrial coefficient datum that was available for author at the time of this analysis is $1989^{\prime}$ s. $^{24}$ So, in order to confirm the relationship of Factor 2 with Ukraine's industrialization, we conducted a

Table 2. Result of Multiple Regression Analysis

\begin{tabular}{|c|c|c|c|c|c|c|}
\hline D_V & year & F_value & Adj_R_S & $\begin{array}{l}\text { Std est. } \\
\text { factor } 1\end{array}$ & $\begin{array}{l}\text { Std est. } \\
\text { factor } 2\end{array}$ & $\begin{array}{l}\text { Std est. } \\
\text { Factor3 }\end{array}$ \\
\hline L_UKR & $\begin{array}{l}1959 \\
1970 \\
1979 \\
1989 \\
\end{array}$ & $\begin{array}{l}227.86^{* *} \\
177.37^{* *} * \\
160.40^{* * *} \\
152.58^{* * *}\end{array}$ & $\begin{array}{l}0.966 \\
0.957 \\
0.952 \\
0.950\end{array}$ & $\begin{array}{l}-0.137 * * \\
-0.075 \\
-0.070 \\
-0.052\end{array}$ & $\begin{array}{l}-0.264^{* *} \\
-0.312^{* *} \\
-0.365^{* *} \\
-0.390^{* *}\end{array}$ & $\begin{array}{l}-0.998^{* *} \\
-0.938^{* *} \\
-0.894^{* *} \\
-0.882^{* *}\end{array}$ \\
\hline L_RUS & $\begin{array}{l}1959 \\
1970 \\
1979 \\
1989\end{array}$ & $\begin{array}{l}143.38 * * \\
158.71 * * \\
151.33 * * \\
155.17 * *\end{array}$ & $\begin{array}{l}0.947 \\
0.952 \\
0.950 \\
0.951\end{array}$ & $\begin{array}{l}0.177^{* *} \\
0.149^{* *} \\
0.153^{* *} \\
0.144^{*}\end{array}$ & $\begin{array}{l}0.369^{* *} \\
0.429^{* *} \\
0.466^{* *} \\
0.501^{* * *}\end{array}$ & $\begin{array}{l}0.977^{* * *} \\
0.900^{* * *} \\
0.850^{* * *} \\
0.844^{* *}\end{array}$ \\
\hline UK UK & $\begin{array}{l}1959 \\
1970 \\
1979 \\
1989 \\
\end{array}$ & $\begin{array}{r}8.19 * * \\
9.88^{* *} \\
11.02 * * \\
15.94 * * \\
\end{array}$ & $\begin{array}{l}0.474 \\
0.526 \\
0.556 \\
0.651\end{array}$ & $\begin{array}{r}0.067 \\
-0.057 \\
-0.126 \\
-0.086\end{array}$ & $\begin{array}{l}-0.132 \\
-0.342 \\
-0.423^{*} \\
-0.478^{* * *}\end{array}$ & $\begin{array}{c}-0.730^{* *} \\
-0.695^{* *} \\
-0.652^{* *} \\
-0.678^{* *}\end{array}$ \\
\hline UK_R & $\begin{array}{l}1959 \\
1970 \\
1979 \\
1989\end{array}$ & $\begin{array}{l}36.72^{* *} \\
62.25^{* *} \\
76.73^{* *} \\
85.14^{* *}\end{array}$ & $\begin{array}{l}0.817 \\
0.885 \\
0.905 \\
0.913\end{array}$ & $\begin{array}{l}0.196 \\
0.118 \\
0.108 \\
0.088 \\
\end{array}$ & $\begin{array}{l}0.216^{*} \\
0.362^{* *} \\
0.413^{* *} \\
0.454^{* *}\end{array}$ & $\begin{array}{l}0.927 * * \\
0.890 * * \\
0.852 * * \\
0.839 * *\end{array}$ \\
\hline UK_UK & $\begin{array}{l}1959 \\
1970 \\
1979 \\
1989 \\
\end{array}$ & $\begin{array}{l}37.44^{* * *} \\
63.53^{* *} \\
77.92^{* *} \\
86.13^{* *}\end{array}$ & $\begin{array}{l}0.820 \\
0.887 \\
0.906 \\
0.914\end{array}$ & $\begin{array}{l}-0.189 \\
-0.112 \\
-0.104 \\
-0.083\end{array}$ & $\begin{array}{l}-0.208^{*} \\
-0.357^{* *} \\
-0.410^{* *} \\
-0.451 * *\end{array}$ & $\begin{array}{l}-0.929^{* *} \\
-0.893^{* *} \\
-0.854^{* *} \\
-0.840^{* *}\end{array}$ \\
\hline R_R & $\begin{array}{l}1959 \\
1970 \\
1979 \\
1989 \\
\end{array}$ & $\begin{array}{r}8.38^{* *} \\
10.35^{* *} \\
11.64^{* *} \\
16.43^{* *} \\
\end{array}$ & $\begin{array}{l}0.480 \\
0.539 \\
0.571 \\
0.659 \\
\end{array}$ & $\begin{array}{r}-0.062 \\
0.073 \\
0.143 \\
0.106\end{array}$ & $\begin{array}{l}0.141 \\
0.361^{*} \\
0.443^{* *} \\
0.498^{* *}\end{array}$ & $\begin{array}{l}0.734^{* * *} \\
0.696^{* *} \\
0.650^{* * *} \\
0.675^{* * *}\end{array}$ \\
\hline O_UK & $\begin{array}{l}1959 \\
1970 \\
1979 \\
1989\end{array}$ & $\begin{array}{l}4.47^{*} \\
4.35^{*} \\
4.46^{*} \\
3.99^{*}\end{array}$ & $\begin{array}{l}0.303 \\
0.296 \\
0.302 \\
0.273\end{array}$ & $\begin{array}{l}-0.285 \\
-0.261 \\
-0.216 \\
-0.137\end{array}$ & $\begin{array}{l}-0.431^{*} \\
-0.431 * \\
-0.410^{*} \\
-0.380\end{array}$ & $\begin{array}{l}-0.554^{* *} \\
-0.489^{* *} \\
-0.470^{*} \\
-0.483^{*}\end{array}$ \\
\hline O_R & $\begin{array}{l}1959 \\
1970 \\
1979 \\
1989\end{array}$ & $\begin{array}{l}10.86^{* *} \\
14.52^{* *} \\
14.76^{* *} \\
14.32^{* *}\end{array}$ & $\begin{array}{l}0.552 \\
0.628 \\
0.632 \\
0.625\end{array}$ & $\begin{array}{l}0.486^{* *} \\
0.486^{* *} \\
0.442^{* *} \\
0.399^{*}\end{array}$ & $\begin{array}{l}0.785^{* *} \\
0.854 * * \\
0.834 * * \\
0.898 * *\end{array}$ & $\begin{array}{l}0.450^{* * *} \\
0.345^{*} \\
0.259^{*} \\
0.199\end{array}$ \\
\hline
\end{tabular}




\section{A METHOD FOR DERIVING DATA}

correlation analysis between the Ukrainian industrial coefficient of 1989 and each province's factor scores on 1989's Factor 2. As a result, the Pearson correlation coefficient reached 0.952 with a significance level of 0.001 . This result suggests the designation of Factor 2 as the industrialization factor.

III. Multiple regression analysis

Three factors were picked out of 15 variables. Next, these three factors' factor scores are regressed to the mother tongue choices, the criteria for the selection of mother tongue ( 8 variables) by each census. In sum, we carried out multiple regression analysis with mother tongue selection criteria as dependent variables and the factor scores for the three factors mentioned above as independent variables.

Each variable's model is summarized in Table 2. As for people who claim Russian as their mother tongue, the industrialization factor as Factor 2 tends to increase its influence on their choice (Standardized estimate increases from $0.37 \Rightarrow 0.43 \Rightarrow 0.47 \Rightarrow 0.50$ from 1959 to 1989 ). To the contrary, the ethnic factor's influence decreases from $0.98 \Rightarrow 0.90 \Rightarrow 0.85 \Rightarrow 0.84$. That is to say, on the one hand the ethnic factor lost while on the other hand the industrialization factor gained influence due to the fact that the number of people who claim Russian as their mother tongue increased over 30 years. The whole model for L_RUS is shown in Figure 3 and multiple regression models for each census are shown in Figure 4 and 5.

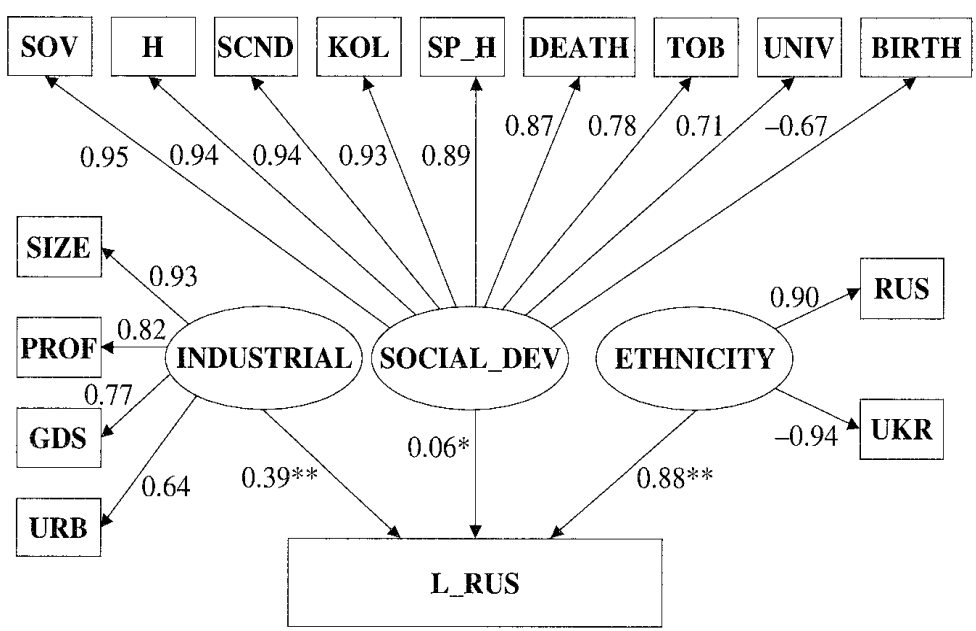

Figure 3. L_RUS model from 1959 to 1989 
Masayuki KUWATA

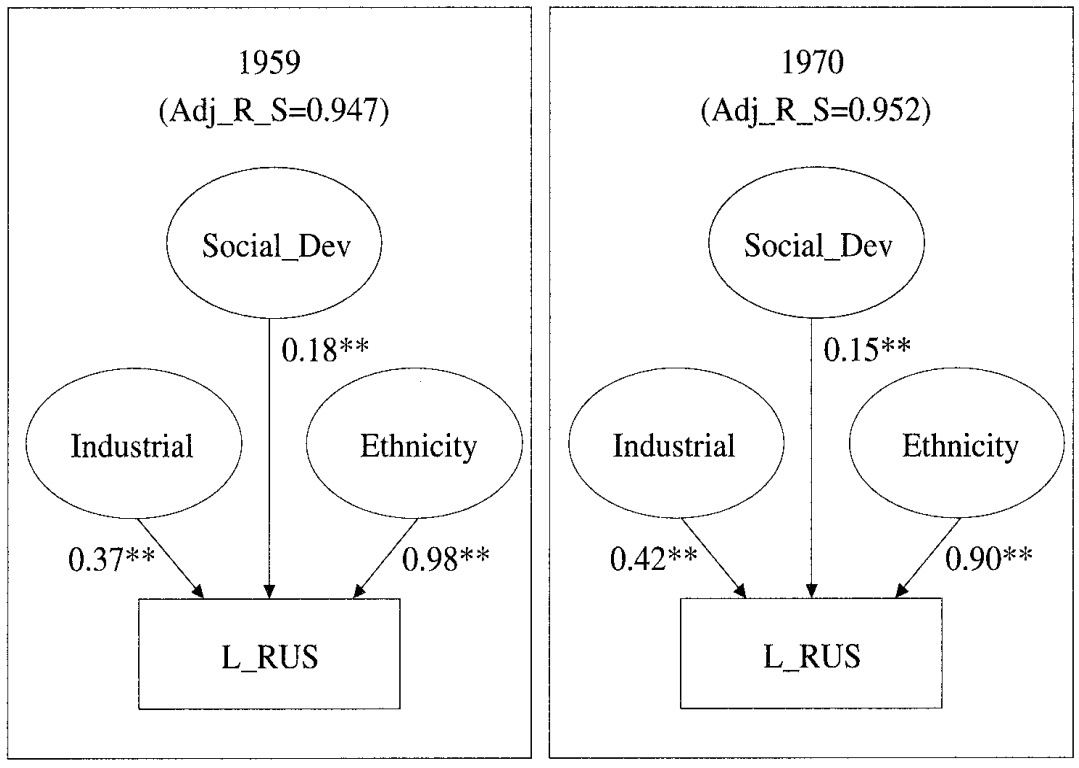

Figure 4. L_RUS Model for 1959 \& 1970

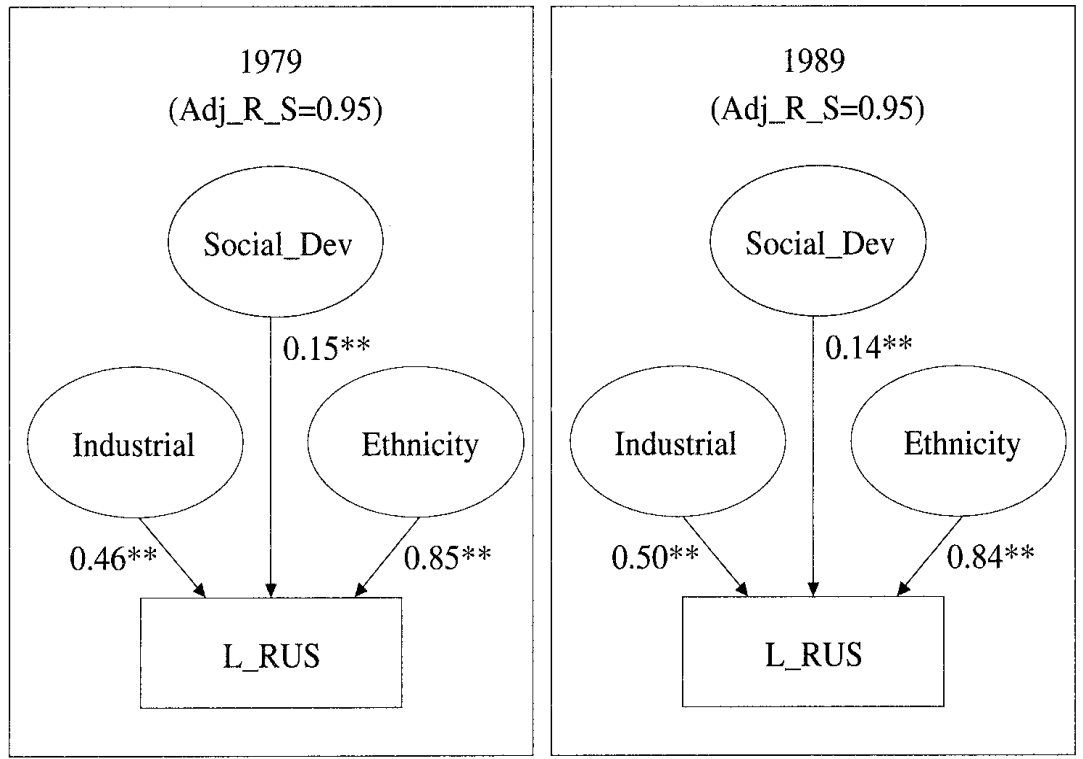

Figure 5. L_RUS Model for 1979 \& 1989 


\section{A METHOD FOR DERIVING DATA}

Other variables' models did not yield results as favorable as the L_RUS model. For example, the L_UK model has a validity problem in Factor 1's standardized estimation. In addition, models such as R_UK, R_R, O_UK, O_R have low scores on the adjusted R_Square. Except for the O_UK model, all models show that the ethnic factor decreases and the industrialization factor increases its influence on mother tongue choices. Therefore, it is concluded that industrialization in the Ukraine strengthened its effect on her citizens' choice of mother tongue.

\section{Conclusion}

This paper achieves the three following points:

1. It not only simplifies the influential model of mother tongue choice but also makes it quite understandable by summing up variables which indicate the three social dimensions.

2. Industrialization in the Ukraine increased its effect on the so-called russification at least during 1959 to 1989 in the long run.

3. Although some significant errors are inherent in the Soviet census, this paper's method offers the possibility to analyze such data under the Soviet regime and to continue the comparative analysis among the former USSR.

The following challenges remain:

1. Confirmation of each variable's validity.

2. Validation and further elaboration of the model.

3. Comparative study with another former USSR's republic data, or extension of the general model for language choice to the former USSR.

\section{NOTES}

1. Dominique Arel, "Language and the politics of ethnicity: The case of Ukraine," University of Illinois at Urbana-Champaign, 1993, pp.90-142.

2. Dominique Arel, "Language politics in independent Ukraine: Towards one or two state languages," Nationalities papers, vol.23, no.3, 1995, p.610, 620.

3. Brian D. Silver, "Methods of Derivinig the data on bilingualism from the 1970 Soviet Census," Soviet Studies, vol.27, no.4, 1975, p.574.

4. Shiokawa Nobuaki, "A little problems in the history of Soviet language policy," Occational papers on changes in the Slavic-Eurasian world, Slavic Research Center, Hokkaido university, 1997, p.11. 


\section{Masayuki KUWATA}

5. Brian D. Silver, "Methods of Derivinig the data on bilingualism from the 1970 Soviet Census," table 3, Soviet Studies, vol.27, no.4, 1975, p.591.

6. Brian D. Silver, "Social mobilization and the russification of Soviet nationalities," American political science review, vol.68, no.1, 1974, pp.53-66.

7. Brian D. Silver, "Language policy and the linguistic russifcation of Soviet nationalities," in Jeremy R. Azrael (ed.), Soviet nationality policies and practices, New York, Praeger, 1978, pp.269-301.

8. "Organizatsionnie i metodologicheskie polodzeniia perepisi naseleniia 1989 g.," Itogi vsesoiuznoi perepisi naseleniia 1989 goda, Tom XII, Minneapolis, East View Publications, 1993, p.655.

9. "Raspredelenie naseleniia oblastei po naibolee mnogochislennim natsional'nostiam i rodnomu iaziku," Itogi vsesoiuznoi perepisi naseleniia 1959 goda, Ukrainckaia SSR, Nendeln, Kraus Reprint, 1975, pp.174-185.

10. "Raspredelenie naseleniia oblastei ukrainskoi SSR po naibolee mnogochislennim natsional'nostiam i iaziku," Itogi vsesoiuznoi perepisi naseleniia 1970 goda, Tom IV, Natsional'nii sostav naseleniia SSSR, soiuznikh i avtonomnikh respublik, kraev, oblastei $i$ natsional'nikh okrugov, Moskva, Statistika, 1973, pp.170-191.

11. "Raspredelenie naseleniia oblastei ukrainskoi SSR po naibolee mnogochislennim natsional'nostiam i iaziku," Itogi vsesoiuznoi perepisi naseleniia 1979 goda, Tom IV, Chast' 1, Kniga 2, Raspredelenie naseleniia SSSR, soiuznikh i avtonomnikh respublik, kraev, oblastei i avtonomnikh okrugov po natsional'nocti i iaziku, Moskva, Goskomstat SSSR, 1989, pp.17-92.

12. "Raspredelenie naseleniia oblastei ukrainskoi SSR po naibolee mnogochislennim natsional'nostiam i iaziku," Itogi vsesoiuznoi perepisi naseleniia 1989 goda, Tom VII, Chast' 2, Natsional'nii sostav naseleniia SSSR, Minneapolis, East View Publications, 1993, pp.24153.

13. ibid.

14. ibid.

15. "Raspredelenie naseleniia oblastei po urobniu obrazovaniia," Itogi vsesoimznoi perepisi naseleniia 1959 goda, Ukrainckaia SSR, Nendeln, Kraus Reprint, 1975, pp.53-61.

16. "Raspredelenie naseleniia SSSR, soiuznikh i avtonomnikh respublik, kraev i oblastei po obrazovaniiu," Itogi vsesoiuznoi perepisi naseleniia 1970 goda, Tom III, Uroben'obrazovaniia naseleniia SSSR, soiuzynikh i avtonomnikh respublik, kraev i oblastei, Moskva, Statistika, 1972, pp.99-105.

17. "Raspredelenie naseleniia respublik, kraev i oblastei po obrazovaniiu," Itogi vsesoiuznoi perepisi naseleniia 1979 goda, Tom III, Chast' 1, Uroben'obrazovaniia naseleniia SSSR, soiuzynikh i avtonomnikh respublik, kraev i oblastei, Moskva, Goskomstat SSSR, 1989, pp.148-157.

18. "Raspredelenie naseleniia soiuznikh i avtonomnikh respublik, oblastei po urobniu obrazovaniia i vozrastu," Itogi vsesoiuznoi perepisi naselenija 1989 goda, Tom VI, Chast'2, 


\section{A METHOD FOR DERIVING DATA}

Uroben'obrazovaniia naseleniia SSSR, Minneapolis, East View Publications, 1993, pp.24153.

19. "Srednemesiachnaia oplata truda kolkhoznikov v obshchestvennom khaziastve po oblastiam," Narodnoe khoziaistvo Ukrainskoi SSR v 1987 godu, Kiev, Tekhnika, p.260.

20. "Srednemesiachnaia zarabotnaia plata rabotnikov sovkhozov po oblastiam," Narodnoe khoziaistvo Ukrainskoi SSR v 1987 godu, Kiev, Tekhnika, p.261.

21. "Raznichnii tovarooborot gosudarstvennoi i kooperativnoi torgovli vkliuchaia obshchestvennoe pitanie po oblastiam", Narodnoe khoziaistvo Ukrainskoi SSR v 1987 godu, Kiev, Tekhnika, p.270.

22. "Chslennost' spetsialistov s visshim i srednim spetsial'nim obrazovaniem zaniatikh v narodnom khoziaistve po oblastiam," Narodnoe khoziaistvo Ukrainskoi SSR v 1987 godu, Kiev, Tekhnika, p.242.

23. "Obshchie koeffitsienti rozhdaemosti, smertnosti i estestvennogo prirosta po oblastiam," Narodnoe khoziaistvo Ukrainskoi SSR v 1987 godu, Kiev, Tekhnika, pp.234-235.

24. "Osnovni pokazniki z kharakteristiki teritorii, naselennia i virobnitstva zemel' ta oblastei Ukraini, 1989 r.," Geografiia Ukraini, L’viv, 1994, p.358. 